\title{
TRADITION AND MODERNITY IN CONTEMPORARY ARCHITECTURE OF TURKEY (COMPARATIVE STUDY REFERRING TO TRADITIONAL AND INTERNATIONAL ARCHITECTURE IN 1940-1980)
}

\author{
Naser Hassanpour \\ Ph. D student in Architecture. Department of Architecture, College of Architecture and Urban \\ Planning, Central Tehran Branch, Islamic Azad University, Tehran, Iran. \\ n.hassanpour@khuisf.ac.ir \\ Hossein Soltanzadeh \\ Associate Professor, Department of Architecture, College of Architecture and Urban Planning, Central \\ Tehran Branch, Islamic Azad University, Tehran, Iran (Corresponding Author). \\ hos.soltanzadeh@iauctb.ac.ir
}

\begin{abstract}
There are a lot of similarities in contrast between tradition and modernity in contemporary architecture of Islamic countries in twentieth century affected by internal factors and international influences. In mentioned years which coincided years after Atatürk's death till the most important contemporary military coup in Turkey, governmental supports of each one of tradition demander and modernist have been accompanied with some internal and external factors in some periods and the contrast of mentioned tendencies forms the contemporary architecture in Turkey. In addition to the identification and classification of Turkey contemporary architecture tendencies and their social and political backgrounds, through investigating each one of tendencies' outstanding architectural monuments, this article is sought to investigate how these works are affected by traditional or international architecture. The ideas of architecture and urban planning famous experts of Turkey have been used for studying and classifying the works or mentioned tendencies and in order to analyze the samples, reliable and diverse sources and field observations have been used. In addition to classifying Turkey contemporary architecture tendencies in mentioned year in three general sub-categories and introducing indicator works of each one of mentioned tendencies, the results of research compare their effectiveness of traditional and international architecture.
\end{abstract}

Keywords: contemporary architecture, Turkey, traditional architecture, international architecture

\section{INTRODUCTION}

Contemporary architecture of Turkey has been changed a lot affected by international transformations and political and social developments in the recent history of this country. More than anything else, contemporary architecture of Turkey is wounded by a sense of duality in the field of cultural identity. During the period of republication, the identity subject lasted with dichotomies such as east-west, religious, secular, national, global. By falling into the unknown abyss of contrast between traditions against modernity, this subject drew attention of political and cultural parties.

Considering the westernized trend, the French, German and American models have been imitated seriously during some specified periods, national trends have been formed in contrast with this approaches in specified periods. The current study investigates Turkey contemporary architecture tendencies in 1940 to 1980 in three known periods based on the ideas of this field scholars and in addition to identifying the approaches of sub-category of each periods, it investigated referring to traditional architecture or following international style in works of each period.

\section{RESEARCH HISTORY}


There have been many researches about the contemporary architecture of Turkey and many of them which are related to second generation of studies about contemporary architecture of Turkey are published mainly in English. While the first generation studies (published in the seventies and eightieth) suffice introducing the tendencies and indicator monuments of contemporary period, the second generation studies that Ms. Sibel Bozdogan is considered as one of its pioneer, investigate the effectiveness of numerous social and cultural factors on architecture and relates urban construction and architecture transformation to social developments among the masses.

After independence war (1920-1922) and announcing Republic of Turkey in 1923, "the beginning of second decade of twentieth century in this country was naturally allocated to repairing destructions and stabilization of the political situation after World War I. the reformations in this country was sought to create a national government on the ruins of the Ottoman Empire. Functional priorities in the field of architecture and urban planning are introduced as below:

1- Constructing service buildings with engineering investment such as nationalization of semi-finished buildings and improving transportation network

2- Restoration of Anatolian cities which were ruined in the war and constructing service buildings with small scale

3- Constructing Ankara as the modern capital city

Republic of Turkey was trying to release itself from Ottoman image and creating a combination of nationalism in ideal Republic" (soheyli \& Diba, 2010: 35). This caused forming a coherent flow in architecture of Turkey. "Due to the urban development of Ankara to a modern city as one of the achievements of the republican government, the profession of architecture faced with a serious challenge. So, the republican leaders, seeking for the solutions, turned to the protagonists of what is now called as "the First National Architecture Movement" (Droudgar \& Fahimfar, 2014:11). The first national architecture movement was an eclectic approach to combine western classical architecture with the principles of Ottoman architecture.

Considering the reluctance of republicans to representation of Ottoman architecture, the transition period didn't last a lot and these conditions have changed since 1927 and considering political events, there have been many efforts for setting up a national government and republic institutions (Soheyli and Majedi, 2011: 54). This period is known as overcoming modern architecture on cubic method in government buildings leading by foreign architectures mainly German ones in Turkey.

\section{METHODOLOGY}

This study is qualitative in terms of content whose base will be interpretive-historical research where in addition to documental studying of social, political and historical backgrounds which have been effective on the contemporary architecture of Turkey, the formed tendencies in the trend of developments in contemporary architecture of Turkey will be introduced and after that, through studying contemporary architecture trends of Turkey and indicator works of each tendencies for documentary and field study, the comparative study between referring traditional architecture or international one in the tendencies indicators of architecture in this period will be investigated.

\section{POLITICAL AND SOCIAL BACHGROUND AND THE FLOWS OF CONTEMPORARY ARCHITECTURE OF TURKEY IN 1940-1950}

After Atatürk's death, there was no conflict about Atatürk's successor. According to Shaw Ismet Inonu the loyal officer to Atatürk who was with him for twenty years from independence wars to renewing Turkey was chosen as president and permanent chairman of the Republican People's Party. He faced two main crises during his presidential years; these two crises included World War II that started less than a year after his arrival and increasing demand for liberal reforms that was discussed after war (Shaw, 1991).

At this time, Turk scholars were drawn to nationalism to imitate the Nazi Germany and Fascist Italy. "The motto of papers such as Arkankon and Bozkurt which were used to be published from 1938 to 
1942 and then since 1948 in Istanbul was "Turkish race is superior to other races". Since then, PanTurkism has been turned into one of ideological bases of ideological carriers, advertising carrier of righties and conservative circles in Turkey" (Entekhabi, 2011: 114).

End of war in Europe didn't mean end of war in Turkey. Soviet pressures on Turkey to join east and 1946 Soviet territorial claims threatened it militarily as well as expanding communist flows and economic crises after war had weakened this country's economy. These pressures led Turkey to emerging global arena power that was America. Turkey's security was guaranteed through announcing Doctrine Truman and Marshal Plan which represented military and economic help of America and as result the international position of Turkey was strengthened and its responsibility in internal investment was reduced.

Only two years after Atatürk's death, national architecture widespread in Turkey while the roots of forming this flow referred to the years of 1930s and architectures' criticism from cubic architecture. Also "In the 1930s Sedad Eldem assumed the leadership of the so-called national architecture movement (milli mimari hareketi) to combat the "Ankara cubic" of Egli and Holzmeiser. Under his leadership a national architecture seminar was established at the academy in 1934. Over the years, this seminar turned into a monumental enterprise to study and document the surviving examples of traditional wooden houses"(Bozdogan \& kasaba , $2001: 263)$.

Winning of Sedad Eldem in competition of Turkish pavilion in 1939 New York Expo which reminded Anatoly vernacular architecture and traditional Ottoman houses enlightened the second national architecture movement. "By 1940 Eldem published the principle theoretical statement on national idiom, (Toward Local Idiom). The Second National Movement had beguan” (Alsac,2005:96).

Eldem considered traditional Turkish houses as modern concept of house and used to admire existing rational and functional logic in these houses and its architectural integration with nature. In addition to Eldem , the role of Bruno Taut, German prominent architect, who admired traditional architecture of Turkey in his articles and speeches, is very important."Generally, many reasons are discussed for reemerging nationalism in the architecture of Turkey that some of them can be mentioned below:

1- Economic crisis derived from Second World War and lack of constructional materials such as steel, glass and cement which were required for modern construction.

2- Psychological influence of Second World War which created national attachment sense and resistance against foreign pressures.

3- Related organizations and ministries' support of setting rules that can create Turk architecture style in order to maintaining coordination and monotony in the face of the city.

4- National architecture seminars in 1934 by Sedad Eldem

5- Ankara's strong relations with the Soviet Union and fascist Italy that caused these two countries to advertise their achievements in the field of nationalism" (Batur, 2005: 33-37).

The focus of second national architecture movement, against the first one which was looking for representation of Ottoman religious architecture, tried to represent Turk civil architecture and using Ottoman traditional houses as representative for these architecture works. On the other hand from the perspective of republican politicians, "the Seljuk period proved to be more acceptable and more fruitful. And , because the Official History Thesis extended " Turkishness " all the way back to Hittite and Mesopotamian civilization, it was now possible to go back to these periods in the search for monumentality as was the case with the Ataturk Mausoleum" (Tekeli,2005:22).

In the years of 1940s, a jury foreman was formed for specifying the approach of these monuments and controlling their characteristics whose reputed people such as Paul Bonatz were famous faces for the second national architecture movement. His effectiveness from the architecture of Turk houses is obviously specified in his most important work in turkey in designing Sarcuglu neighborhood in Istanbul. In late 1940, there were more than 300 activated architectures in Turkey. They could form an effective lobby for the exclusion of foreign architects. 


\section{POLITICAL AND SOCIAL BACKGROUND AND THE FLOWS OF CONTEMPORARY ARCHITECTURE OF TURKEY IN 1950-1960}

The fifties of the twentieth century was major developments period in the lives of Turkish in many ways. "After a two-party system was establish in 1946 the democrat party came to power with the elections on May 14,1950. Development strategies were now to emphasize the role of private sector"'(Tapan,2005:105).Democrat party started their liberal reformations rapidly. The democrats who were in power made a severe driving force in Turkey. New Prime Minister Adnan Menders led the new policy without any control and tried to get the country away from Atatürk's policy that was still reputed all around Turkey. The plan of new reformations was a lot but any promises who were made couldn't reach the desired result.

In conditions that internal crises had Turkey faced with a lot of problems, "In foreign policy, Turkey's pro-Western reorientation continued during the 1950s. ... The founding of NATO in 1949 prompted Turkey's application for membership the next year. ... The Turkey of the 1950s could not have experienced growth in both its economy and its military without such investment"(Vaughn Findely,2010:309).

The years of 1950s were the years of Turkey passing the crises after the war and emerging new party of democrat as a modern party with populist attitudes in politic scene of Turkey. "With their rule a rather liberal approach quickly took hold and private entrepreneurship gained importance. In this context, the architectural community had a chance to satisfy their demands for governmental support on private practice"(Imamoglu,2010:64). Private employers became increasingly important.

In this era "A younger generation of Turkish architects established themselves in private practice outside state patronage and produced works that reflect the aesthetic canons of international style in all its post-war variations: from the American corporate style of the 1950s to works of LeCorbusier and Latin American modernism. Manifested itself primarily in austere-looking government complexes, educational buildings and cultural institutions, cutting-edge architectural production after 1950 was most visible in hotels, offices, shopping centers, commercial and recreational projects, with taller apartment blocks emerging as the dominant residential typology"(Bozdogan \& Ackan,2012:107).

In this era the concept of west changed from Europe to America for Turks. "1950s presented a clear "Americanization" in building and life culture, parallel to the shift in the conception of the "West" in the society. The flow of foreign aid from US to Turkey at the time, and the accompanying aspiration to become "the little America", determined the new direction of identity and its suiting architecture"(Balamir,2003:39).

The presence of America was simultaneous with the European architectures leaving that the years before had main role in professional training of architecture in Turkey. "After the end of the World War in 1945 some foreign architects returned to their countries. But a more important fact that affected their practice was the campaign in the Turkish architectural scene against their dominance, which had its solid result in 1954 with the law on the newly founded Union of Chambers of Turkish Engineers and Architects"(Imamoglu,2010:52).

From the effective factors on the architecture of this era according to Tapan, the cases below can be mentioned. First, the rapid growth of cities made comprehensive master planning a necessity. Second, the construction industry expanded rapidly to answer increasing demand. Third, a law governing buildings was introduced in the Grand National Assembly in 1951. In an attempt to regulate and discipline architectural activity, the ministry of Public Works issued new regulations for planning and architectural competitions. Finally, the Turkish Chamber of Architects was establishing by the law no.6235 of 1954 (Tapan, 2005).

Close relationship with west and availability of materials and western techniques besides economic development in this era caused constructing residential apartments in expensive parts of cities that middle class couldn't afford buying houses in those areas. Luxury and the using western model in 
designing plan and the size of these buildings prevailed a new lifestyle imitating west in big cities of Turkey. In the years of 1950s and 1960s affected by economic developments and Turkey moving toward industrialization and its ongoing modernization process in contemporary era, "Migration to towns, housing shortage, and lack of sufficient accumulation of capital gave way to urbanism that operated with relentless pragmatism and speculative interests"(Balamir,2003:35).

\section{POLITICAL AND SOCIAL BACKGROUND AND THE FLOWS OF CONTEMPORARY ARCHITECTURE OF TURKEY IN 1960-1980}

Finally after protests of different classes, in May $27^{\text {th }} 1961$ the army took the control of company by a coup which is named as "National Modern Revolution". "There was no resistance against the coup of militaries in 1960 and overthrowing the government of Adnan Menders. Even university professors, students and the other middle class groups who were the main supporters of the Democrats in the 1950 election turned to main adversary force of Menders government" (Rajabzadeh \& Fazeli, 2012: 87).

After the coup, military generals left the power for politicians through election and therefore the new constitution was adopted in 1961 and the second era of republication started. "While the early years of sixtieth century were simultaneous with increasing social freedoms and establishing economic program, rapid industrialization and fair distribution of wealth, economy crisis in the end of the decade sparked a wave of unrests which were manifested through street unrests, labor strikes and political assassination. Students and workers' movements of the left side formed that were competing the right side and national militant groups" (Zurcher, 2004: 258). "On the contrary, following the multi-party politics, two direct military coups in 1960 and in 1980 occurred. In addition, in 1971 and 1997, indirect interventions were witnessed. The recent case of e-memorandum shows that the TAF still sees itself as the ultimate guarantor of the regime. ... The military elites need to change their behavior and threat perceptions for the sake of democratic consolidation of Turkey"(Burak , 2011 : 165-166).

Conditions in Turkey in the years after 1970 were on the wane. "The post-1973 years were the worst period for Turkey to be led by weak and indecisive governments totally lacking in direction. Not only did the economy have to cope with the oil-price shock of 1973, it had also to absorb the blows of the European economic downturn which ended the demand for Turkish labour"(Ahmad , 2002:176).

"Despite a great deal of social unrest, the two decades between 1960 and 1980 saw important new developments: the growth of industry and business, the emergence of pluralistic world view and new concepts introduced by it, the establishment of an urban way of life with its concomitant attitudes and values, and the rise of social consciousness which pervaded current thought. These constitute the causal background for the architectural ideas of the last two decades" (Yucel , 2005,121).

Affected by a multi-party flow governing society in the years 1960-1980 which were known as tumultuous years in the contemporary history of Turkey; freedom of expression and pluralism of social ideas, a kind of polyphony and discontinuity could be seen in architecture and urban constructing of Turkey. With increasing social consciousness, social knowledge became more important in architecture era. With expanding industrialization in Turkey "Another phenomenon influencing architectural practice after1960 was rapid industrialization. First building materials industries for the domestic market were established. These industries were not aimed at solving or rationalizing the housing problem in Turkey; their object was the middle and upper-class housing produced by contractors" (Tekeli, 2005:28). In late years of this era, economic recession stopped mentioned projects.

Because of political turmoil during these years and lack of stable political power with developed program and parallel economic and industrial development of Turkey, now big holding companies and banks had turned to appropriate employers for architectures. Industrial development of Turkey and modern architecture becoming endemic in turkey created a huge development in construction method. "During the period of its preeminence, social criticism had concerned itself with form only in two cases. First in an attempt to create the so called "New National Architecture" it unavoidably referred to the earlier National Movements, and provided them with a social content. Second, it searched for a 
new theoretical synthesis, inspired by the works of Tafuri and structuralism, and the latters impact on Marxist thought" (Yucel, 2005:123).

Table 1- Political and social background and the flows of contemporary architecture of Turkey in 1940-1980, source: the author

\begin{tabular}{|c|c|c|}
\hline & Social and political backgrounds & Architecture and urbanism revolution \\
\hline 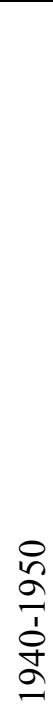 & $\begin{array}{l}\text { Political and economic crisis of subsequent } \\
\text { war years and the spread of nationalism to } \\
\text { resist external pressures } \\
\text { Inonu substitution instead of Ataturk - liberal } \\
\text { freedom } \\
\text { joining the West in The Marshall and } \\
\text { Truman Plan in the late } 40 \\
\text { the creation of the religious and opposed first } \\
\text { trends }\end{array}$ & $\begin{array}{l}\text { German architects role in managing } \\
\text { professional training and Architecture } \\
\text { education } \\
\text { The economic crisis caused by the war and } \\
\text { restrictions on the import of building products } \\
\text { Turkish public support for a coordinated plan } \\
\text { for government buildings } \\
\text { acceptance of the Hittite and Urartu and Seljuk } \\
\text { architecture as Turks architecture } \\
\text { The second national movement with a focus on } \\
\text { traditional houses architecture and civil } \\
\text { architecture and vernacular Anatolian } \\
\text { Architectural competition and the role of Paul } \\
\text { Bonatz in leading the competitions } \\
\text { Focus on the study of vernacular architecture } \\
\text { and traditional houses in architecture education }\end{array}$ \\
\hline 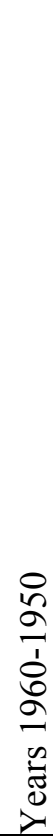 & $\begin{array}{l}\text { Emerging Democratic Party with populist } \\
\text { policies. } \\
\text { Alliance with the West and Europe - } \\
\text { following the American model in all aspects } \\
\text { - financial and military aid of America. } \\
\text { Strengthening the agricultural sector } \\
\text { according to populist policies. } \\
\text { chaos and economic stagnation and political } \\
\text { terror in the late 50s as a result of } \\
\text { government mistakes. }\end{array}$ & $\begin{array}{l}\text { availability of Western construction methods } \\
\text { and forms of international modernism- } \\
\text { developing expensive homes-promoting } \\
\text { international modernism. } \\
\text { promoting American modernism to imitate the } \\
\text { Hilton Hotel integration of architectural and } \\
\text { plastic arts (painting, sculpture, etc). } \\
\text { Urban sprawl and promoting modernism } \\
\text { contractor and the formation of marginal } \\
\text { illegal settlements (Jeckondu). } \\
\text { The law of } 1958 \text { to manage construction and } \\
\text { cooperatives } \\
\text { The prevalence of private sector housing } \\
\text { construction and builders and sellers. } \\
\text { Historical context destruction due to the } \\
\text { expansion of urban highways. } \\
\text { Establishment of the chamber of Architects and } \\
\text { middle east technical university based on the } \\
\text { American model. }\end{array}$ \\
\hline
\end{tabular}




\begin{tabular}{|c|c|c|}
\hline 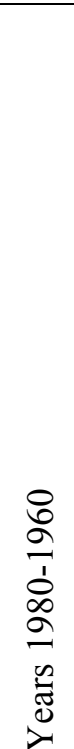 & $\begin{array}{l}\text { The first military coup and changing } \\
\text { Constitution- the beginning of the Second } \\
\text { Republic. } \\
\text { then the second coup in } 1970 \text { and third in } \\
1980 \text {. } \\
\text { Economic growth in } 60 \text { 's and unprecedented } \\
\text { inflation and recession in the } 70 \text { plus } \\
\text { political turmoil and terror. } \\
\text { Increasing social consciousness - expanding } \\
\text { urban lifestyle. } \\
\text { Establishing a weak coalition governments. } \\
\text { Expansion of Industry and Commerce in the } \\
60 \text { - imports of luxury goods. } \\
\text { Expansion of extremist ideas of pan-Turkism } \\
\text { and left and right trends. } \\
\text { The spread of uncontrolled migration to } \\
\text { cities. }\end{array}$ & $\begin{array}{l}\text { Increasing social conscience and impact of } \\
\text { social knowledge on architecture. } \\
\text { Holding companies and banks and the private } \\
\text { sector as an employer, industrialization } \\
\text { buildings and designing industrial buildings. } \\
\text { Pluralism in architectural trends among the } \\
\text { leading architects. } \\
\text { Opening Bogaz bridge and Kocatepe mosque. } \\
\text { Increasing student population and faculty of } \\
\text { architecture and unemployment crisis between } \\
\text { architects - the difference between the left and } \\
\text { right tendencies in architecture education. }\end{array}$ \\
\hline
\end{tabular}

\section{IDENTIFYING THE TENDENCIES OF CONTEMPORARY ARCHITECTURE OF TURKEY IN YEARS 1940-1950}

Referring to traditional architecture was accomplished in the flow of second national movement with focus on referring traditional Ottoman houses architecture especially in academic and professional circles. But beside this flow, other forces such as Pan Turkism that through discussing "Turkish history thesis" (TTK in Turkish) was looking for representation of architecture of Turkey before Islam and especially Hettite and Urartu architecture on one hand and on the other hand German and Italian fascist architecture and Soviet socialist architecture as the other forces were effective in contemporary architecture of this era.

While Batur refers to three approaches in the architecture of second national movement, according to Tekeli, four separated approaches can be specified in this era which is more acceptable in terms of scholars. The first approach is regionalism approach that based on it the architectures should pay attention to cultural continuity in architecture as well as using local materials and conforming to climate conditions of the country. Faculty of Language, History and Geography in Ankara (Image 1 and 2) designed by Bruno Taut is the excellent sample of this tendency. Bruno Taut who was considered as the adversaries of modern movement focused on the sense of touch and structural ornaments instead of shells devoid of modern architecture decoration.

He also avoided mere nativist and believed that native and traditional components should be used besides modern construction method. Referring building to Turkish architecture because of using alternating walls of stone and brick (Almashik) in the method of early republication in lateral wings and turquoise sharp tiled decorating in entry hall has been accepted (Aslanoglu, 1980). The tangible transformation from stone to plaster in lateral view and accurately set details between window frame and stone especially designed gutters and lamps, curved shells and prominent details of nobs can be mentioned as prominent features of this building. "Just as in many of high schools, Taut used a specific window detail by with sun-shading beams placed at mid-height. Avowedly inspired by "old Turkish houses"(Bozdogan \& Ackan,2012:64). Besides this building, Faculty of Science and Literature in Istanbul is considered as another prominent monument where constructed historicity architecture principles or rationalist neoclassical with monumental buildings and symmetrical building have been combined with elements of traditional Ottoman houses such as wide and continuous eaves and Chikma Windows pattern (Image 3).

The second approach can be named as nostalgic architecture. This approach was looking for past brilliant view and tried to show that past values are still validate. "Gabriel argued that Istanbul houses were actually modern and would yield better results than cubic architecture if only wood were to be 
replaced by concrete"(Tekeli,2005:21). Eastern cafe (Tasilik Coffee house) in Istanbul (Image 4) and Turkey Pavilion in global exhibition of 1939 in New York are considered as prominent works of this style.

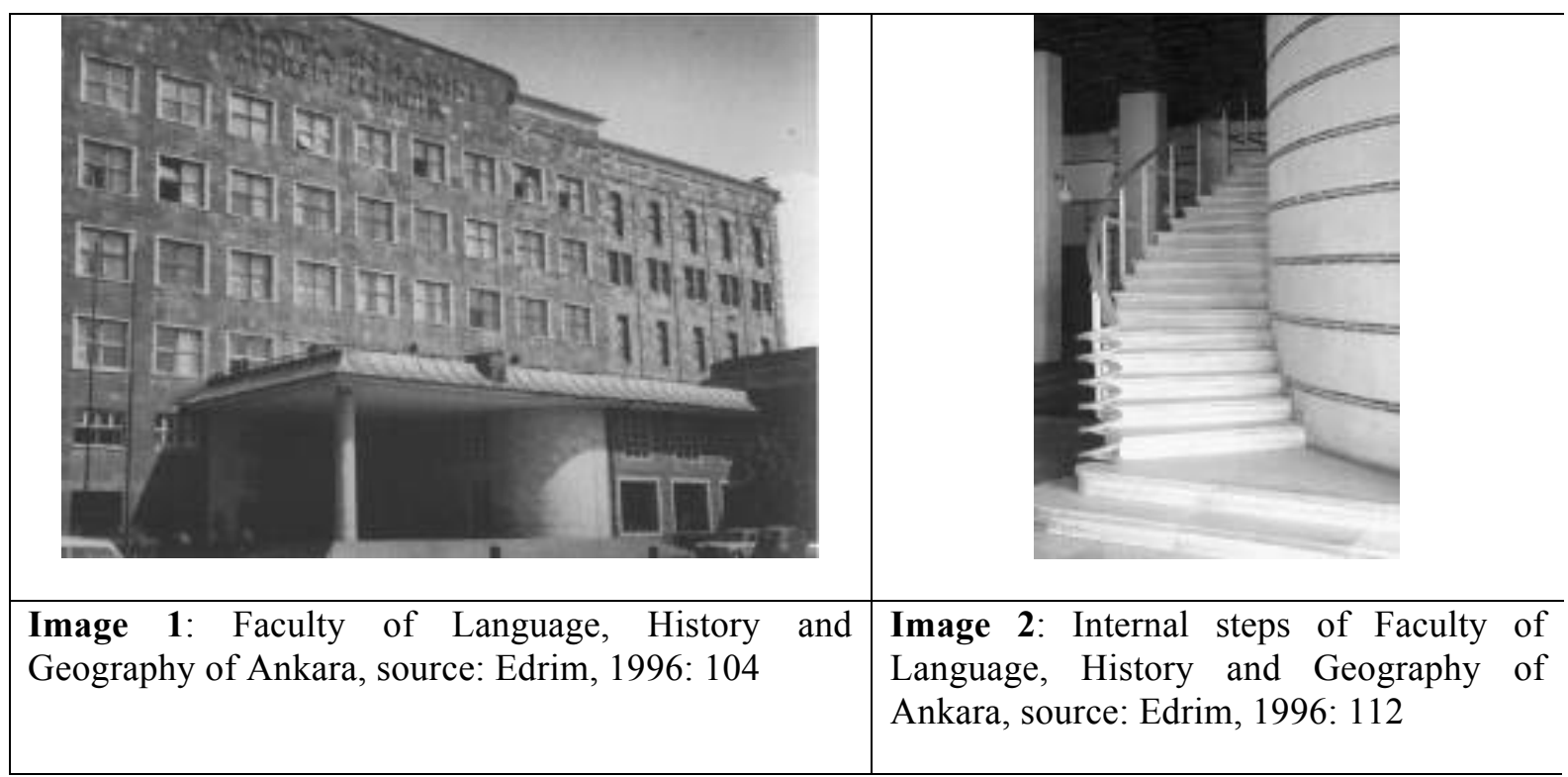

In tasilik coffee house of Eldem, getting effect from Turkish traditional houses was obviously clear. The general form of building reminds us Ottoman villas in the form of a pavilion in the garden. Completely concrete rigid Platform like middle spaces and mass in ground floor and light structure upper floor make this effect more clear. "This historical building where regional architecture features were completely obvious in it only used to follow modern architecture principles in execution. Building of coffee house referred to traditional large central sofa diagram which had lateral masses which ended to a central cubic space which was opened to four directions" (Batur, 2005: 39).

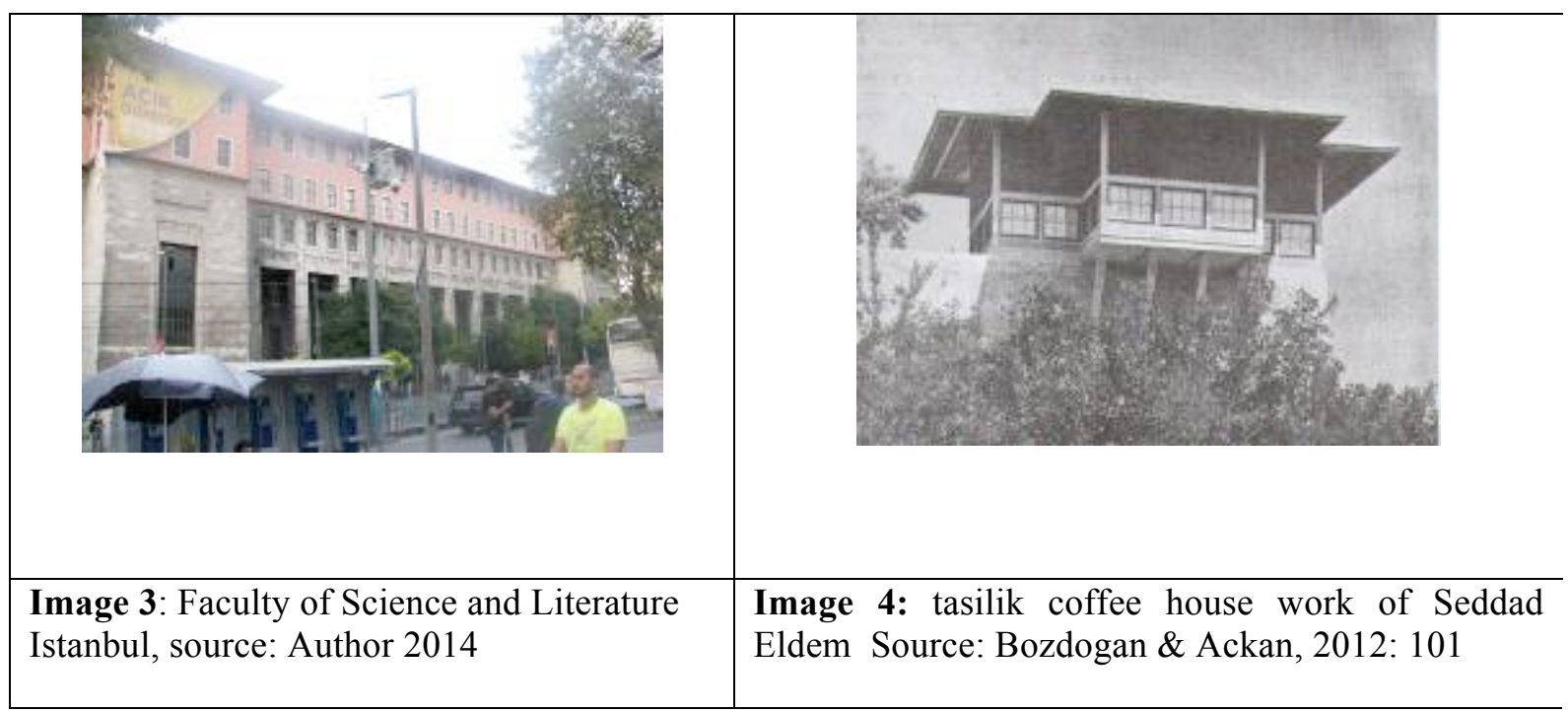


Image 5: Kosuyolu housing project, work of ozden and Turgat , source: Holod \& Evin, 2005: 165

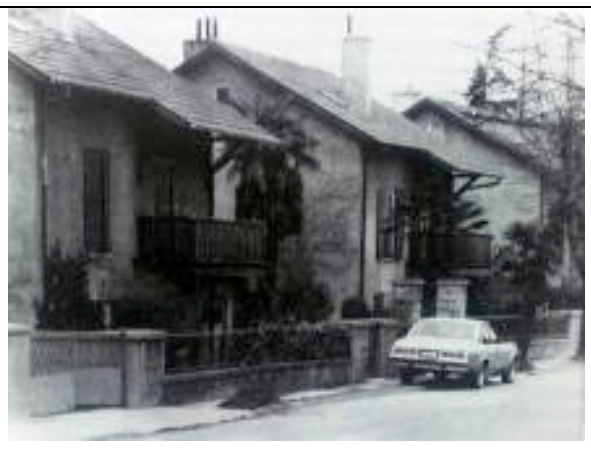

The third approach instead of upper class of Istanbul is populist approach which is raised from Anatoly which focus on Anatoly unknown and sustainable life values. The ideas of Oelsner can be considered as representative in recreating Anatolian life patterns in urban plans. The houses designed by Emin Onat like Cenap house and housing construction project of Kosuyolu (Image 5) the work of Ozden and Turgat and the first housing project of Levent (First Levent District) work of Aru and Gurbon are considered as prominent works of this tendency.

The fourth approach which is called Chauvinist focus on monumentalism in building and looks for Turkish historical representation in architecture works and referring classical architecture and Atatürk's mausoleum (Image 6) designed by Emin Onat and Orhan Arda can be considered as the sample of this style.

The plan of this building was formed in a big international competition that Paul Bonatz had a significant role in choosing the final plan as a referee. "It is traditional as well as modern; it combines the Turkish tradition of "turbe" and Anatolian tradition of mausoleum in a new, modern manner. It employs traditional building materials and construction methods as well as modern ones. It makes use of traditional decoration as well as of art forms of non-Turkish origin such as reliefs and status. It is monumental but still has a geometrical simplicity of fine proportions and excellent detail"(Alsac,2005:100-101). This building is a constructed manifest from a theory that relates the history of the people of mediterranean and world civilization to the history of Turkish people.

\section{IDENTIFYING THE TENDENCIES OF CONTEMPORARY ARCHITECTURE OF TURKEY IN YEARS 1950-1960}

With the arrival of imported goods to Turkey in the field of construction industry and economic contributions of America and availability of modern technique and activity in foreign companies in the construction field of Turkey and emerged tendencies in urban modern life, international architecture was preferred on traditional and vernacular architecture in Turkey.

Inspiration for architects in the late 50 included two categories, "The first was American corporate modernism, especially the glass curtain wall epitomized by such projects as Lever House, New York (1952) by Skidmore, Owings \& Merrill (SOM) or Mies van der Rohes Seagram Building (1958), both of which were widely publicized by the architectural media at the time. ... The second, equally powerful influence was that of the post-war work of Le Corbusier, especially the paradigmatic Unite $d$ Habitation (1948) as well as the Corbusian work of Latin American and Caribbean architects”(Bozdogan \& Ackan,2012:115-116).

As the most important building of first approach, Hilton Hotel in Istanbul (Image 7) which was designed by S.O.M and the cooperation of Seddad Eldem as local architecture and rapidly turned into splendid symbol of American modernism on a hill in the prominent position in Istanbul. Modular Plan and view with the cubic volume and concrete structure in years after that became the pattern for many buildings in Turkey such as Cinar Hotel and Istanbul City Hall. "It is also a textbook case of modern architectures role in U.S Cold War politics, at a time when the designs of U.S embassy buildings and Hilton hotels were seen as powerful visual instruments of projecting a positive image of America abroad"( Ibid:116).Other prominent buildings such as cultural center of Ataturk designed by Hayati 
TabanLioglu with glass curtain wall facing Taksim Square and organization of Water Affairs Management with similar pattern are considered as the followers of this approach.

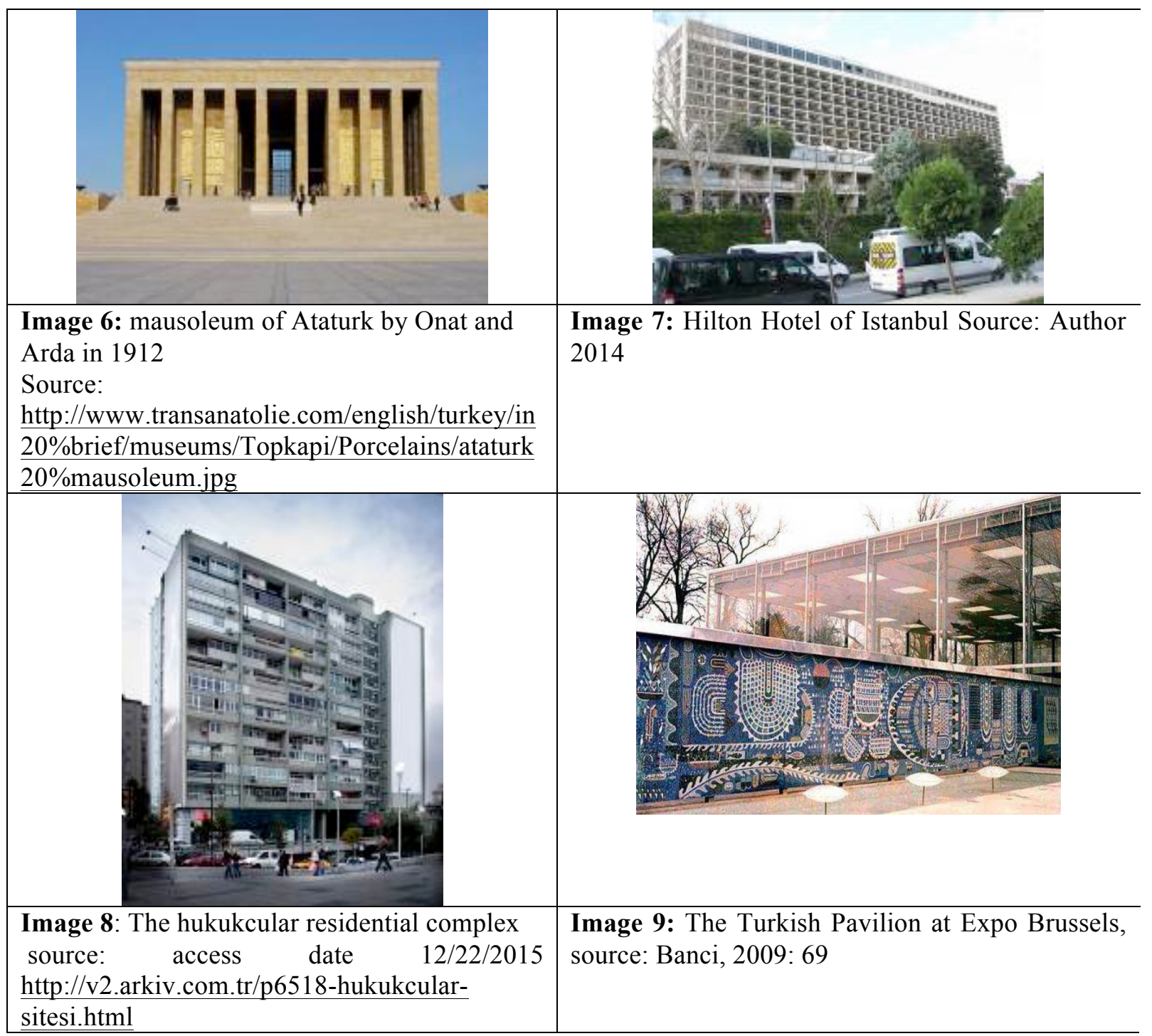

Many residential buildings were built in Turkey based on second approach such as hukukcular residential complex (Image 8) designed by Haluk Baysal and Melih Birsel that represented the idea of Le Corbusier's united habitation with its all components such as the pilot, a garden terrace, and central street and its aesthetic principles. The other important building in this approach is Cinnah 19 apartment building. The architect of project Nejat Ersin has clearly stated that during designing this project, he had been inspired with international architecture and some architects such as Le Corbusier, Oscar Niemeyer, Lucio Costa and Edward Durell were his inspiration. For example the building of housing unit in Marseille has been noticed by him.

At this time, in interaction with the mentioned approaches in designing state buildings. "Another argument against the alleged monotony of 1950s Turkish modernism can be found in the "integration of plastic arts", or the collaboration between architects, painters, muralists and sculptors. ... During the 1950s and 60s many prominent Turkish architects including haluk Baysal, melih Birsel, Utrait Izgi , Turgat Cansevar, and Abdurrahman Hanci, worked on the synthetic idea of combining modernist concept of space and construction abstract/non-figurative original artworks"(Ibid:130). 
The best sample of that was formed in designing Turkish Pavilion at Expo Brussels (Image9). In criticizing this work Bozdogan refers the interaction between tradition and modernity and interaction between architecture and other arts as well as the role of national-state of Turkey in global exhibition. Using some of details related to Hettit architecture in interior spaces refers to old civilization of Turkey and wall tessellation is also reminder of Ottoman architecture.

\section{IDENTIFYING THE TENDENCIES OF CONTEMPORARY ARCHITECTURE OF TURKEY IN YEARS 1960-1980}

Years of the 1960s and 1970s are the years of sequential shift in the political system and freedom of speech and polyphony in social and cultural fields. This fragmentation was also repeated in architecture and urban construction either affected by lack of supporting a special approach by governmental system. "Distinguished architects of late 60s and 70s turned from International Style to variations on Organic Architecture and new Brutalism. The formal articulation of both surrendered soon to the mainstream paradigm, through applications of several formulae: using irregular of geometries in plan composition and/or fragmenting bulky forms into smaller scale masses, and subdivision of facades with numerous mullions revealing the modular order. Sedad Eldems Social Insurance Institution (Image 10) embodying such formulate was the model to many buildings for decades to come"(Balamir,2003:33).

Converting the huge constructional blocks to fragmented blocks which acted coordinated with environmental traditional texture beside abstract function of architecture features of Anatoly traditional houses beside modern aesthetics in total view of building drew attention in this work and brought Aga Khan Prize for this building. Combination of aesthetic principles in was repeated in this building besides the idea of industrialization in Istanbul Trade Center building (Image 11) designed by Orhan Shahinler, a building whose design reminds us modern monumentalism.

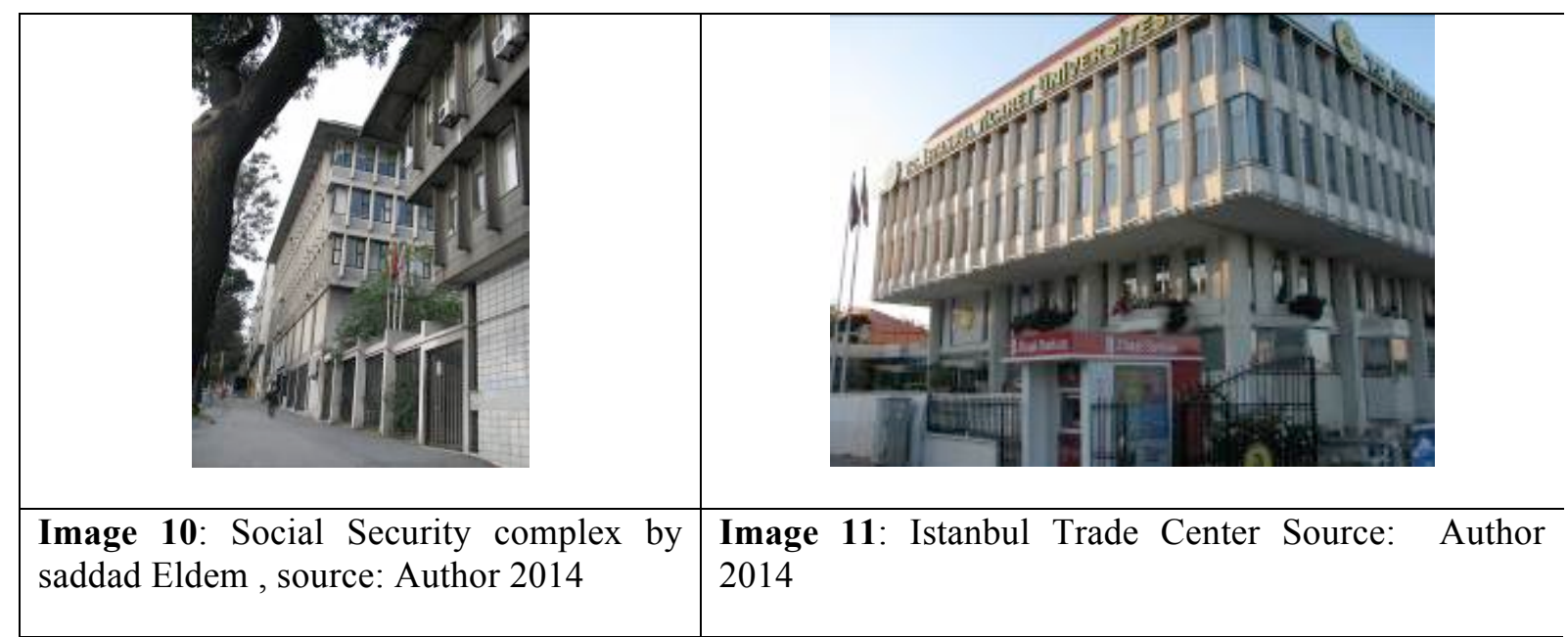

The other effective architecture of this period was Turgut Cansevar who had Phenomenological view to the history in architectural. Using architectural words which related them to the historical texture that it was located there and the function of decorations in detail used to appear clearly in his works. His most important work was Turkish historical society (Image 12) that inspiring with the pattern of Turkey historical schools showed the function of light and materials in a conceptual form and with particular sensitivity to the available ground and texture and hidden values in past architectures. "For turgat Cansevar, Semantics related to historicity in architecture have a metaphysical significance . They derive from "the unity of forces and the commandments of being [which] determine existence and its community. He also calls the communicative ways of this existence and continuity "ornamentality," a concept he advocates"(Yucel, 2005:125).

Following modern brutalism pattern in Middle East Technical University by Behruz Cinicci and Altug Cinicci was very effective in expanding this idea in many other architecture works. The existing aesthetics in the design of this building was inspired by different sources. The effect of Japanese architecture, Alvar Aalto, Bakema, Rodulph, Gowan and Stirling architecture can be seen in this 
building. "METU department of architecture was the first building in turkey presenting such character. In its architectural form, being still almost in pristine state, there are visible many solutions typical of brutalism, such as : strong articulation of solids composed in an orthogonal geometry ; the use of raw buildings materials - concrete sun-breakers, gargoyles and cornices. Altug and Behruz Cinicci were also inspired by local architecture and that's why the building brutalist but also traditional"( Zelef \&Niebrzydowski,2012:21).

In designing different sections of Middle East technical university besides modern brutalism ideas, following organic architecture in American style of Frank Lloyd Wright and Germany organic architecture as well as Alvar Aalto can be clearly seen. The features of organic architecture are obviously clear in the plan of university auditorium. Plasticity curved surfaces coated with cement plaster and rows of bricks on the side of free-form can be clearly seen in designing this building. Such these features can be also seen in the building of Central Library of the University of Istanbul designed by Hadi brothers. Of course the first organic architecture tendencies refer to Sheraton Istanbul hotel building, a building whose construction lasted from 1974 to 1985.

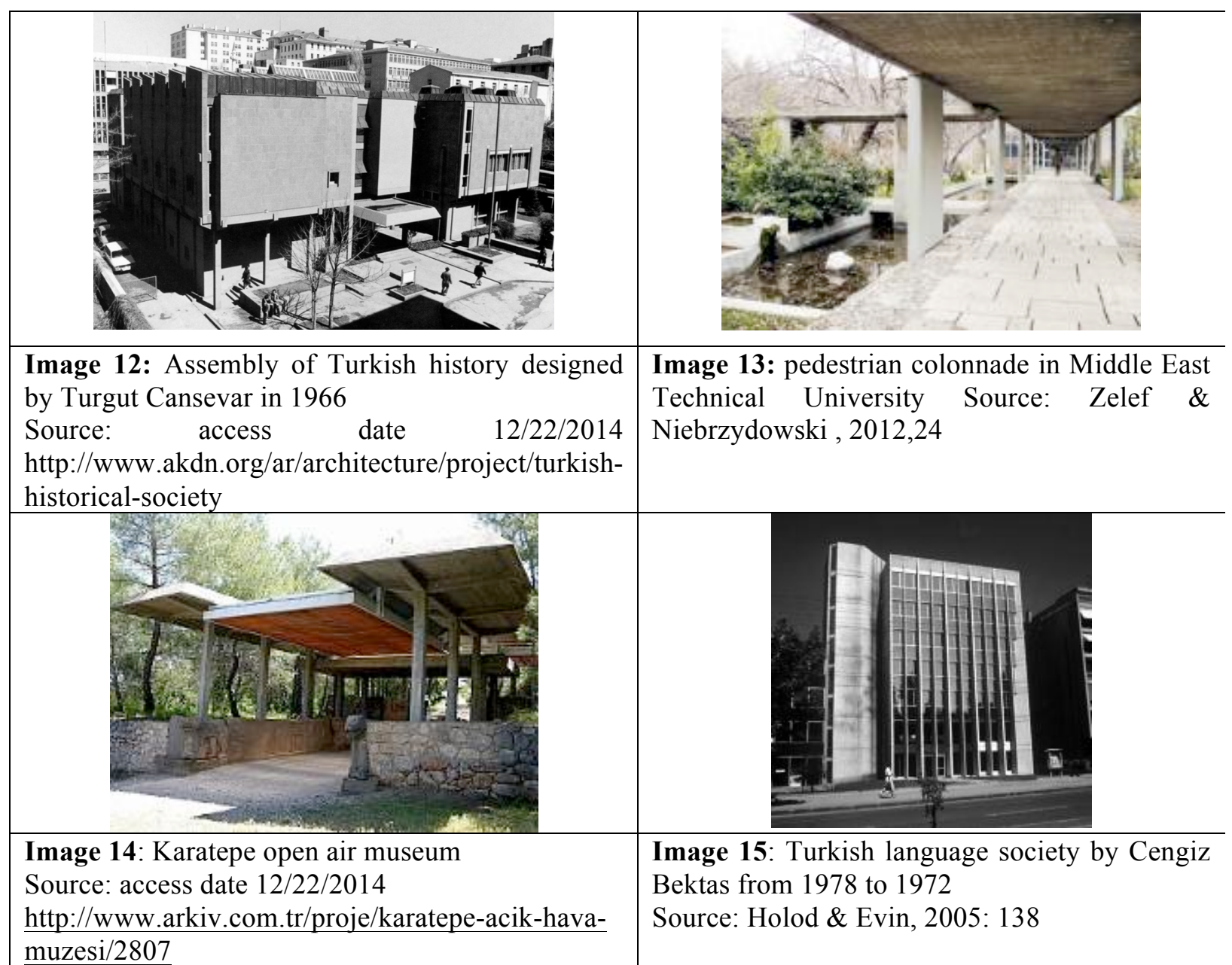

The other prominent tendency in the architecture of this era can be seen in open air museum of Karatepe by Turgut Cansevar in the form of regionalism modern architecture. The definition of Anatoly vernacular and regional architecture components in modern form has been noticed a lot in this work. "In a series of articles written in 1961-2 Kuban defined the new regionalism as a response to "environmental conditions", which he elaborated as rational and candid evaluation of a countries facts. He insisted that Actual Regionalism would be different from historicism, folklorism and nationalism, or from any version of a priori formalism, a category in which he included the international style"(Bozdogan \& Ackan , 2012:186). 
On the other hand modern monumental orientation was appeared in combination with technology development in high-rise tower architecture such as the Odakule tower and I.S.Bank tower. In this period the quality of symbolism or monumental architecture in architecture occurred through the height or extreme horizontality in buildings where looking for achieving a united expression by form. Technology and evolution in details and expensive materials which used to be represented by huge business in simple forms with form single word, created a new method in monumental architecture in the works of this period. The building of Turkish language society (Image 15) by Cengiz Bektos and AKBank by Eldem are considered as prominent works of this era.

While the contrast of mentioned tendencies forms the total face of two sixtieth and seventieth decade, the discussed tendencies in fortieth and fiftieth in spite of that are place in two decades in two adversary pole, are more aligned. Table 2 separates the mentioned tendencies in 1940 to 1980 in Turkey and investigates the traditionalism or modernism (international) features in these works.

Table 2- tradition and modernity in Turkey contemporary architecture approaches in 1940-1980

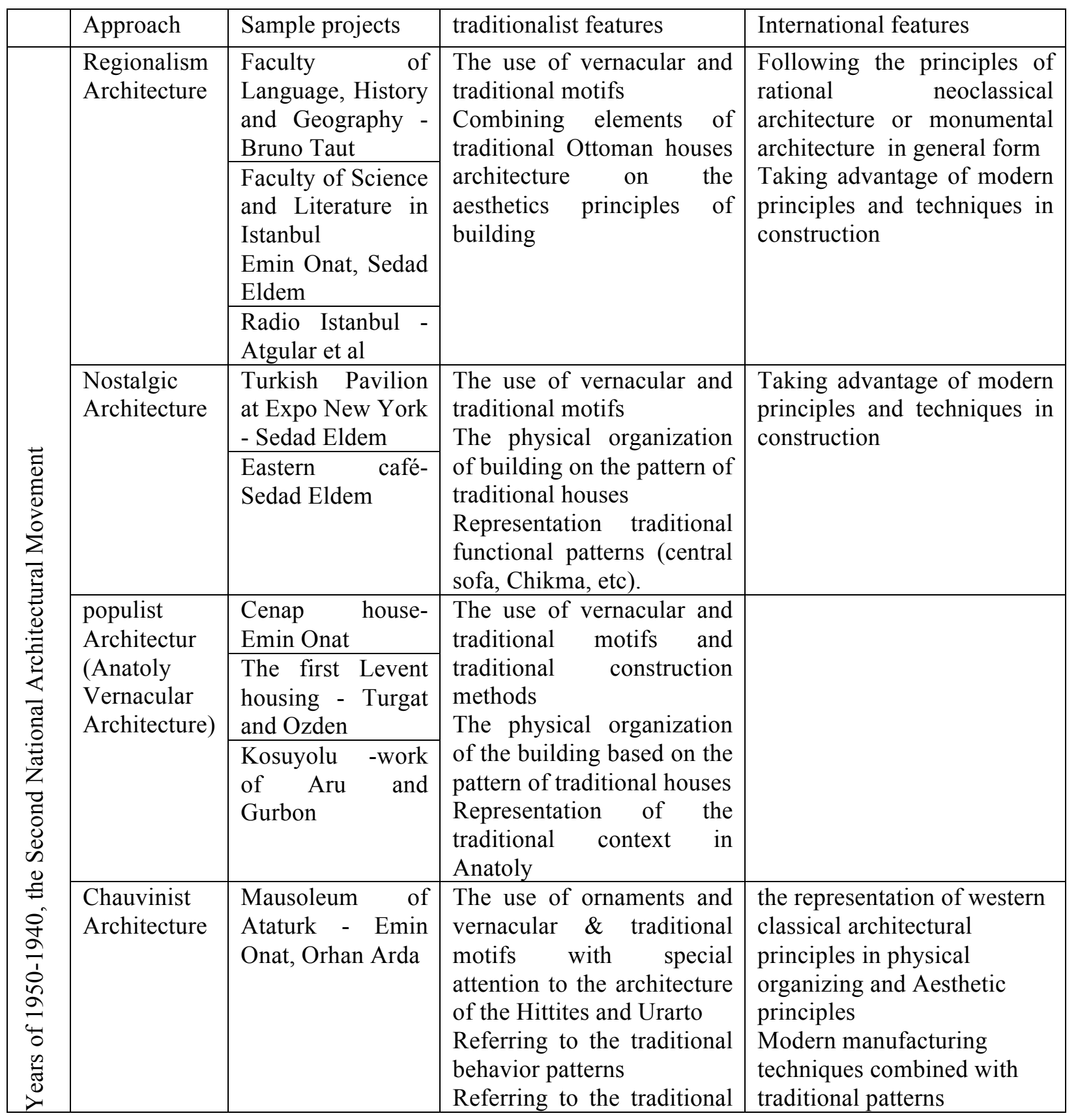




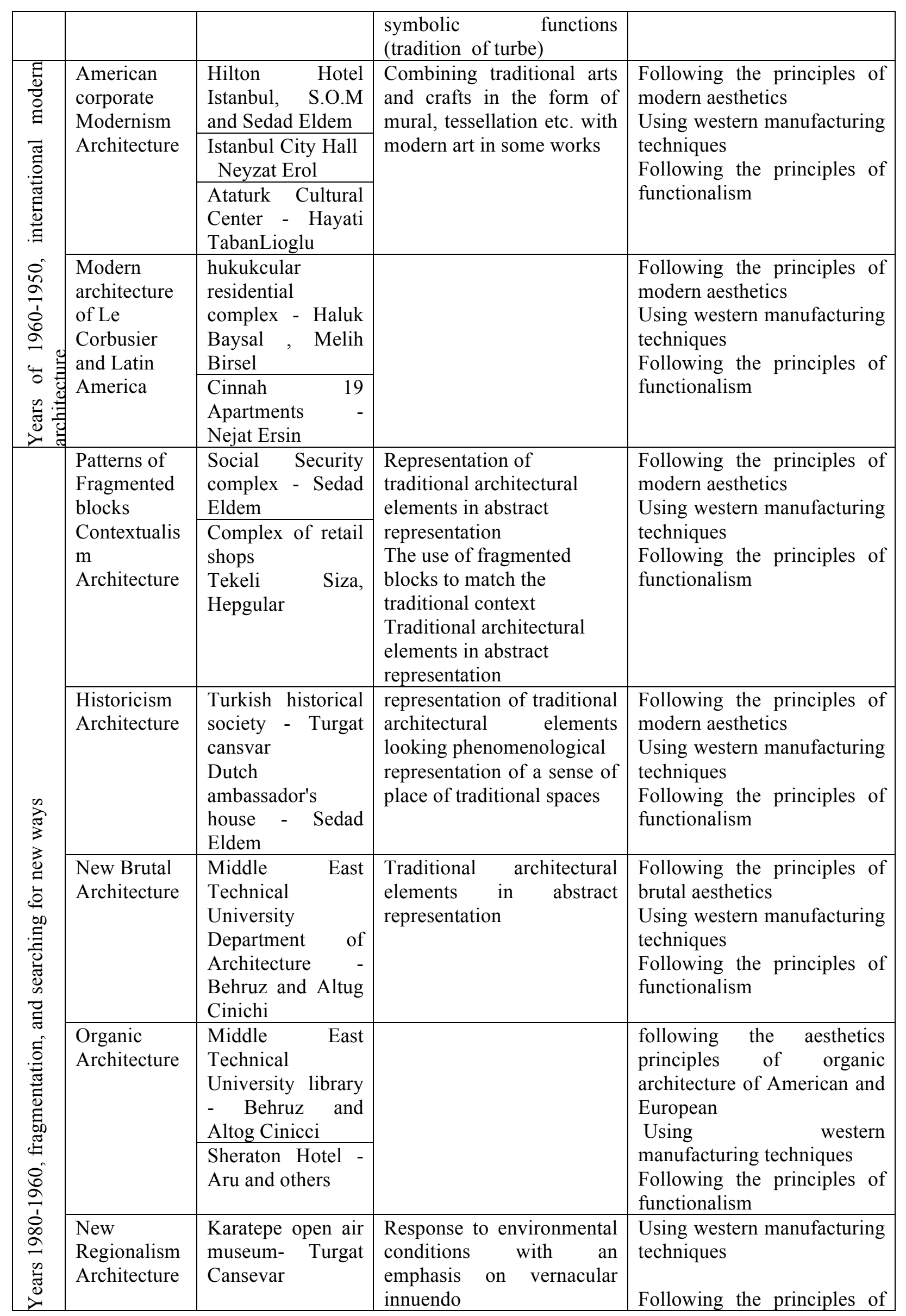




\begin{tabular}{|l|l|l|l|l|}
\hline & & $\begin{array}{l}\text { Traditional architectural } \\
\text { elements in abstract } \\
\text { representation } \\
\text { The use of traditional } \\
\text { materials and techniques }\end{array}$ & functionalism \\
\cline { 2 - 5 } & $\begin{array}{l}\text { New } \\
\text { Monumental } \\
\text { ism }\end{array}$ Architecture & $\begin{array}{l}\text { I.S Bank Tower - } \\
\text { bokeh, Yilmaz, } \\
\text { Sargyn }\end{array}$ & $\begin{array}{l}\text { Representation } \\
\text { traditional architecture } \\
\text { principles in physical } \\
\text { Surkish language } \\
\text { society by Cengiz } \\
\text { Bektas }\end{array}$ & $\begin{array}{l}\text { Taking advantage of Western } \\
\text { manufacturing techniques } \\
\text { relying on perfect details } \\
\text { Following the principles of } \\
\text { functionalism } \\
\text { Single expression in physical } \\
\text { form }\end{array}$ \\
\hline
\end{tabular}

\section{CONCLUSION}

Investigating the developments of contemporary architecture in Turkey represents wandering between two poles of referring traditional architecture and imitating western architecture. This is an event that has happened similarly in other countries such as Iran. About Turkey and in studied periods, the role of governmental policies in tending to each one of mentioned pole is important in the first two decades which have been accompanied with internal and external cultural and social development. In the years of $1940 \mathrm{~s}$, traditional architecture is preferred considering the architecture of traditional Ottoman houses. Discovering traditional Ottoman houses and recognizing the rational properties hidden in it was aligned with the tastes of republicans and caused that republican politicians look at these houses as the symbol of Turk modern nation in global era. This subject besides backgrounds of war crisis and the year after that and governmental policies in creating coordinated theme in architecture of state buildings with forming some institutions for planning and controlling this flow led to forming the second national architecture movement. While affected by multi forces forming this flow, different branches were emerged in the architecture of these years, all of their abonnement was recognizing and representing traditional and vernacular architecture of Turkey that included a wide period of recent years till ancient era.

The advent of the Democratic Party as the head of Turkey government in 1950s was accompanied with particular western tendencies especially America and the elimination of backgrounds of the postwar crisis. Tending to international architecture in these years was place on the opposite side of architecture in 1950s. While following international architecture principals in prominent projects of this decade used to be done with high international quality and standard, the most emergence of this flow in following west in contractor vernacular modernism and technocratic modernism only noticed a little aspect of producing architecture.

The years of 1960s and 1970s was accompanied with polyphony in dominant political flows and lack of induction trend towards one of two poles of traditional and vernacular architecture and international architecture. Simultaneously with vernacular of modern manufacturing techniques and reducing the role of state employers, numerous tendencies emerged in architecture which were raised from developing society of Turkey and each one in an style was seeking to combine Turkish traditional architecture with update architecture flows in western method and tried to introduce its method as a pattern for Turkey modern architecture in new world.

While following western known methods can be seen as a whole or a small detail in all this emerging tendencies, the method of referring to traditional architecture in these tendencies is significantly different. While some tendencies such as modern monumental architecture and modern brutal referred to the traditional architecture only in the field of form and aesthetic principles, in historicism tendencies referring traditional architecture occur deeper and in all three categories of form, function and meaning. General estimation of mentioned tendencies in 1960 and 1970 shows combination of traditional architecture with western architecture in overarching theme. 


\section{REFERENCES}

Ahmad, F(2002) "The making of modern turkey".London: Routledge.

Alsac, U.(2005) "The second period of turkish national architecture" (2th ed.). Published in Modern turkish Architecture by Renata Holod and Ahmet Evin . Pennsylvania :University of Pennsylvania Press.

Aslanoglu, Inci (1980)"Erken Cumhuriet, Donemi Mimarligi”, Ankara :ODTU.

Banci , S. (2009) "Turkish Pavillion In The Brussles Expo 58: A Study On Architectural Modernization In Turkey During The 1950s", A Thesis Submitted To The Graduate School Of Social Science Of Middle East Technical University, Advisor :Proffessor Sencer Ayata.

Balamir, A.(2003) Architecture and exercise of identity : A profile of building culture in modern Turkey, Abadi quarterely journal of architecture \& uvbanism, 13(38),20-43.

Batur ,A.(2005)"A Concise History : ARCHITECTURE IN TURKEY During the 20 th Century",Ankara: Published by the chamber of Architects of Turkey.

Bozdogan, S And Kasaba, R .(1997) "Rethinking Modernity and Identity in Turkey",Washington: University of Washing press.

Bozdogan,S.( 2007) "Reading Ottoman Architecture through Modernist Lenses: Nationalist Historiography and the "New Architecture" in the Early Republic". In Muqarnas: An Annual journal on the Visual Culture of the Islamic World, 1(22), Pages 199-221.

Bozdogan,S And Esra, A .(2012) "Turkey: Modern architecture in history", London :Reaktion Books Ltd.

Burak , Bogum (2011) "The role of the military in Turkish Politics : The Guard whom and form what “, Euro pean Journal of Economic and Political Studies . 4(1) 2011. Pages 143-169.

Doroudgar A, Fahimfar A. (2014) "Recognition of Govermental Nationalist Policies Role in the Rise of National Architecture Movements in Turkey and Iran(1920-1950CE"). American journal of Social Sciences,Art and Literature; 1(1): 01-22.

Entekhabi, N.(2011) Nasionalism and Modernity in Iran and Turkey, Tehran: Negare Aftab Publication.

Edrim , B . (1996) ," From Germany to Japan and Turkey ; Modernity, Locality and Bruno Tauts Trans-National Details From 1933 to 1938 “, Lunch , 102-115.

Imam oglu , B. (2010) "Architectural Production in State offices : An Inquiry into the professionalization of Architecture in Early Republican Turkey", PhD thesis . Netherland: Technical University of Delft .

Rajabzadeh, A \& Fazeli, M.(2008) Social classes and democracy: the comparative historical analysis of Iran, Turkey and South Korea, Iranian Journal of Sociology(ISA), 8(2),112-141.

Shaw, S.J \& Shaw, E.K.(2002)History of Ottoman empire and modern Turkey, Volume II: Reform, Revolution, and Republic: The Rise of Modern Turkey, 1808-1975, New York, Cambrige university Press.

Soheili, J \& Diba, D.(2010) How Government Systems Have Influenced the Emergence of Nationalist Architectural Movements in Iran and Turkey, Bagh-I-Nazar Quarterely journal of Art,Architecture \& Urbanism, 7(14),27-44.

Soheili, J \& Majedi, H.(2011) Emergence of modernism in Turkish architecture and its encounter with national architectural movements, HoviateShahr Quarterely journal of Art,Architecture \& Urbanism, $5(9), 49-58$.

Tapan, M.(2005)" international style:liberalism in architecture" (2th ed.). Published in Modern turkish Architecture by Renata Holod and Ahmet Evin . Pennsylvania :University of Pennsylvania Press.

Tekeli, Ilhan.(2005) "the social context of the development of architecture in turkey (2th ed.).: Published in Modern turkish Architecture" by Renata Holod and Ahmet Evin. Pennsylvania :University of Pennsylvania Press.

Vaughn Findely, C.(2010) "Turkey, Islam , Nationalism and modernity". New Haven:Yale University Press.

Yucel ,A(2005) "pluralism takes command: the turkish architectural scene today" (2th ed.). Published in Modern turkish Architecture by Renata Holod and Ahmet Evin . Pennsylvania :University of Pennsylvania Press. 
Zelef, H \& Niebrzydowski,W .(2012) Brutalism And METU Department Of Architecture Building In Ankara , Architecture Civil Engineering Environment" , The Silesian University Of Technology , 2012(2), pages :21-30

Zurcher, E, J.(2004)" Turkey : a modern history”. London: I.B.Tauris \& Co Ltd.

Karatepe Aslantaş Açık Hava Müzesi , Yrd. Doç. Dr. İlker Fatih Özorhon, Maltepe Üniversitesi Mimarlık Fakültesi , Available from : http://www.arkiv.com.tr/proje/karatepe-acik-havamuzesi/2807, Accessed 2015/12/22

Hukukçular Sitesi , Available from : http://v2.arkiv.com.tr/p6518-hukukcular-sitesi.html , Accessed 2015/12/22.

Turkish Historical Society, Available from: http://www.akdn.org/ar/architecture/project/turkishhistorical-society, access date 12/22/2014 